University of Wollongong

Research Online

Faculty of Engineering and Information

Faculty of Engineering and Information

Sciences - Papers: Part B

Sciences

2017

The effect of cooling rate and coiling temperature on the niobium retention in Ultra-Thin Cast Strip steel

Zhizhang Wang

University of Wollongong, zw537@uowmail.edu.au

Kristin R. Carpenter

University of Wollongong, kristinc@uow.edu.au

Zhixin Chen

University of Wollongong, zchen@uow.edu.au

Chris R. Killmore

BlueScope Steel Limited, Chris.Killmore@bluescopesteel.com

Follow this and additional works at: https://ro.uow.edu.au/eispapers1

Part of the Engineering Commons, and the Science and Technology Studies Commons

Research Online is the open access institutional repository for the University of Wollongong. For further information contact the UOW Library: research-pubs@uow.edu.au 


\title{
The effect of cooling rate and coiling temperature on the niobium retention in Ultra-Thin Cast Strip steel
}

\begin{abstract}
This laboratory study utilised a dilatometer to simulate the run-out table cooling rate and the coiling temperature to investigate the effect of the cooling rate and simulated coiling conditions on the age hardening response of a niobium microalloyed Ultra-thin Cast Strip $\left(\mathrm{UCS}^{\circledR}\right)$ steel, produced by the CASTRIP ${ }^{\circledR}$ Process. Three cooling rates of 1,5 and $40{ }^{\circ} \mathrm{C} / \mathrm{s}$, covering very slow $\left(1{ }^{\circ} \mathrm{C} / \mathrm{s}\right)$ to typical run-out table cooling rates $\left(40^{\circ} \mathrm{C} / \mathrm{s}\right)$, down to two coiling temperatures of 500 and $675^{\circ} \mathrm{C}$ were used. Dilatation curves were used to determine the temperature range over which the $i-i$ phase transformations occurred and the final microstructures were characterized using an optical microscope equipped with an image analysis software. The subsequent age hardening response, which previous studies have shown, results from the retention of $\mathrm{Nb}$ in solid solution, was assessed by the hardness changes after a post heat treatment at $700{ }^{\circ} \mathrm{C}$ for $60 \mathrm{~s}$. A range of age hardening responses were obtained, depending on cooling rates and cooling stop (coiling) temperatures, which indicate a different degree of $\mathrm{Nb}$ retention. At the same cooling rate, the lower coiling temperature of $500^{\circ} \mathrm{C}$ resulted in higher $\mathrm{Nb}$ retention compared to the higher coiling temperature of $675^{\circ} \mathrm{C}$. As the coiling temperature of $675^{\circ} \mathrm{C}$ was within the austenite to ferrite transformation range, the simulated slow cooling of the coil impacted the precipitation behaviour of $\mathrm{Nb}$ rendering the interpretation more complex and this will be discussed in this paper. For the $500{ }^{\circ} \mathrm{C}$ simulated coiling temperature, the higher cooling rate resulted in a higher age hardening increment thus more $\mathrm{Nb}$ retention.
\end{abstract}

\section{Disciplines}

Engineering | Science and Technology Studies

\section{Publication Details}

Wang, Z., Carpenter, K., Chen, Z. \& Killmore, C. (2017). The effect of cooling rate and coiling temperature on the niobium retention in Ultra-Thin Cast Strip steel. Materials Science and Engineering A: Structural Materials: Properties, Microstructure and Processing, 700 234-240. 


\title{
The effect of cooling rate and coiling temperature on the niobium retention in Ultra- Thin Cast Strip steel
}

\author{
Zhizhang Wang $^{a}$, Kristin Carpenter ${ }^{\text {ac }}$, Zhixin Chen ${ }^{a *}$ and Chris Killmore \\ ${ }^{a}$ School of Mechanical, Materials,Mechatronic and Biomedical Engineering, University of Wollongong, Wollongong, NSW2522, Australia \\ ${ }^{b}$ Research \& Development: Sales \& Marketing, BlueScope Steel Ltd., Port Kembla, NSW 2505, Australia \\ ${ }^{C}$ Plate Mill: Manufacturing, BlueScope Steel Ltd., Port Kembla, NSW 2505, Australia
}

A R T I C L E I N F O

Article history:

Keywords:

Dilatometry

CASTRIP steel

thermomechanical processing

age hardening

phase transformation

precipitation

\begin{abstract}
A B S T R A C T
This laboratory study utilised a dilatometer to simulate the run-out table cooling rate and the coiling temperature to investigate the effect of the cooling rate and simulated coiling conditions on the age hardening response of a niobium microalloyed Ultra-thin Cast strip (UCS $\left.{ }^{\circledR}\right)$ steel, produced by the CASTRIP ${ }^{\circledR}$ Process. Three cooling rates of 1,5 and $40^{\circ} \mathrm{C} / \mathrm{s}$, covering very slow $\left(1^{\circ} \mathrm{C} / \mathrm{s}\right)$ to typical run-out table cooling rates $\left(40^{\circ} \mathrm{C} / \mathrm{s}\right)$, down to two coiling temperatures of 500 and $675^{\circ} \mathrm{C}$ were used. Dilatation curves were used to determine the temperature range over which the $\gamma$ - $\alpha$ phase transformations occurred and the final microstructures were characterized using an optical microscope equipped with an image analysis software. The subsequent age hardening response, which previous studies have shown, results from the retention of $\mathrm{Nb}$ in solid solution, was assessed by the hardness changes after a post heat treatment at $700^{\circ} \mathrm{C}$ for $60 \mathrm{~s}$. A range of age hardening responses were obtained, depending on cooling rates and cooling stop (coiling) temperatures, which indicate a different degree of $\mathrm{Nb}$ retention. At the same cooling rate, the lower coiling temperature of $500^{\circ} \mathrm{C}$ resulted in higher $\mathrm{Nb}$ retention compared to the higher coiling temperature of $675^{\circ} \mathrm{C}$. As the coiling temperature of $675^{\circ} \mathrm{C}$ was within the austenite to ferrite transformation range, the simulated slow cooling of the coil impacted the precipitation behaviour of $\mathrm{Nb}$ rendering the interpretation more complex and this will be discussed in this paper. For the $500^{\circ} \mathrm{C}$ simulated coiling temperature, the higher cooling rate resulted in a higher age hardening increment thus more $\mathrm{Nb}$ retention.
\end{abstract}

\footnotetext{
* Corresponding author: Zhixin Chen

E-mail address: zchen@uow.edu.au
} 


\section{Introduction}

CASTRIP ${ }^{\circledR}$ process is a revolutionary strip casting technique for producing Ultra-Thin Cast Strip steel, which has many advantages over conventional casting and rolling technologies, including a smaller carbon foot print, lower cost of production and simpler and more flexible operating conditions. The world's first commercial installation of the CASTRIP process for the production of Ultra-Thin Cast Strip (UCS) is located in Nucor Steel's Crawfordsville, Indiana plant. The facility has been producing low-carbon sheet steel since its startup in 2002 [1]. The CASTRIP process is mainly composed of three parts: twin-roll casting, hot rolling reduction, controlled cooling process. The strip is produced from liquid steel with a rapid solidification rate by twin-roll casting, followed by hot rolling reduction to final thicknesses of 0.9-1.5 mm. Finally, on the run-outtable, the steel is controlled cooled by air-mist water cooling. The control of the cooling rate and the stop cooling temperature on the run-out-table plays an important role in achieving the desired microstructure and mechanical properties of the UCS products.

There are several strengthening mechanisms operating in Nb microalloyed UCS steel [2-5], including microstructural hardening, and solid solution hardening. In addition, due to the retention of $\mathrm{Nb}$ in solid solution [2], age hardening, through the precipitation of $\mathrm{Nb}$ rich particles, can be utilized to further strengthen $\mathrm{Nb}$ microalloyed UCS steel by post-processing operations, such as during continuous hot dip galvanising [3]. It is well known that the effective precipitation hardening performance can be achieved by a post heat treatment if more $\mathrm{Nb}$ retained in solid solution after the CASTRIP process. In addition, it is important to note that the cooling rate and the coiling temperature on the run-outtable, not only can have a significant effect on the retention of $\mathrm{Nb}$, but also on the microstructure and the mechanical properties of the strip. Therefore, in order to effectively control the mechanical properties of the CASTRIP product, it is necessary to study the influence of the cooling rate and coiling temperature on the $\mathrm{Nb}$ retention in UCS steel in CASTRIP process.

A considerable amount of research works, about the influence of cooling conditions on precipitation hardening, focused on diffusion time and diffusion rate of solute atom during continuous cooling process [6]. While only a small number of studies focused on major precipitation region in which the solute atoms precipitate out during cooling control process [7]. Therefore, the aim of the present study was to further investigate the potential effect of the cooling rate and coiling temperature on the retention of $\mathrm{Nb}$ in solid solution during the controlled cooling process over a wider range of processing conditions than can practically be achieved under industrial run-out table cooling conditions, viewed from phase transformation temperature range where the NbC precipitates are mainly produced. To undertake this study, the age hardening response, as measure by the change in hardness, was utilised to reflect the retention of $\mathrm{Nb}$ in solid solution in Nb microalloyed UCS steel.

\section{Experimental procedure}

UCS steel strip produced by the CASTRIP process used in the present study was supplied by BlueScope Steel, Port Kembla, and the chemical composition is listed in Table 1.

The thickness of the strip was $1 \mathrm{~mm}$, so it was too thin to make standard sized dilatometry samples. An alternative sample design, rectangular shape with an arm on each end, was used in this investigation, as shown in Figure 1. The heat treatment experiments were carried out on a Theta Industries-Dialatronic dilatometer.

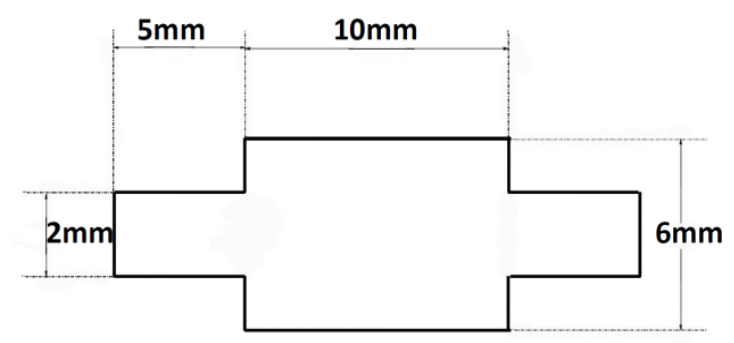

Figure 1 . The geometry of the dilatometery samples.

The dilatometry experimental program is schematically shown in Figure 2. The experimental conditions are aimed to simulate the thermal path of the Castrip processing though they do not include a hot deformation step to simulate the hot rolling process. The absence of a hot deformation component was not considered significant to the aims of this study, given the low hot rolling reductions usually applied and the short time period after hot rolling, before cooling is applied, that restricts strain induced precipitation occurring. The samples were heated to the solution temperature of 1280 ${ }^{\circ} \mathrm{C}$ at $20^{\circ} \mathrm{C} / \mathrm{s}$ and held for 5 minutes under vacuum to simulate the coarse austenite grain size in as-cast UCS. Specimens were then cooled to $900^{\circ} \mathrm{C}$ at $50^{\circ} \mathrm{C} / \mathrm{s}$, to simulate the relatively rapid cooling of thin strip between casting and hot rolling. After a 60 second dwell period at $900^{\circ} \mathrm{C}$, the samples were cooled to the coiling temperature of either 500 or $675^{\circ} \mathrm{C}$, at three different cooling rates of 1,5 or $40^{\circ} \mathrm{C} / \mathrm{s}$, respectively. To simulate the slow cooling of a coil, the samples were cooled to $300^{\circ} \mathrm{C}$ at the cooling rate of $0.17^{\circ} \mathrm{C} / \mathrm{s}$ from the coiling temperatures, before helium gas quenching to room temperature.

Table 1: Chemical composition (wt.\%) of the UCS steel.

\begin{tabular}{|c|c|c|c|c|c|c|c|c|c|c|c|}
\hline Element & $\mathrm{C}$ & $\mathrm{P}$ & $\mathrm{Mn}$ & $\mathrm{Si}$ & $\mathrm{S}$ & $\mathrm{Ni}$ & $\mathrm{Cr}$ & $\mathrm{Mo}$ & $\mathrm{Cu}$ & $\mathrm{Nb}$ & $\mathrm{N}$ \\
\hline & 0.031 & 0.014 & 0.738 & 0.159 & 0.003 & 0.047 & 0.057 & 0.017 & 0.095 & 0.059 & 0.005 \\
\hline
\end{tabular}




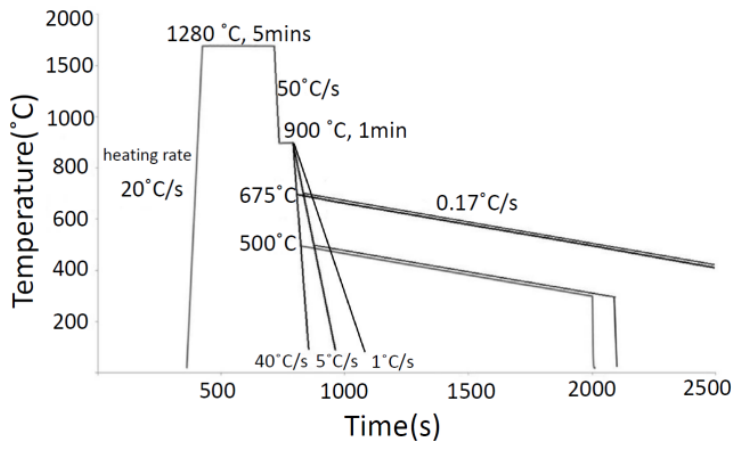

Figure 2. Schematic illustration of the Heat treatment simulation for the CASTRIP process.

The heat treated samples were divided into two parts by using an Accutom 5/50 sectioning machine. One part was used for the microstructure characterisation and hardness measurements, while the other part was utilised for the post-processing age hardening treatment, which was carried out in the dilatometer. These samples were aged at $700^{\circ} \mathrm{C}$ for 60 s and cooled to room temperature by helium gas quenching, as shown schematically in Figure 3 , then the hardness was measured.

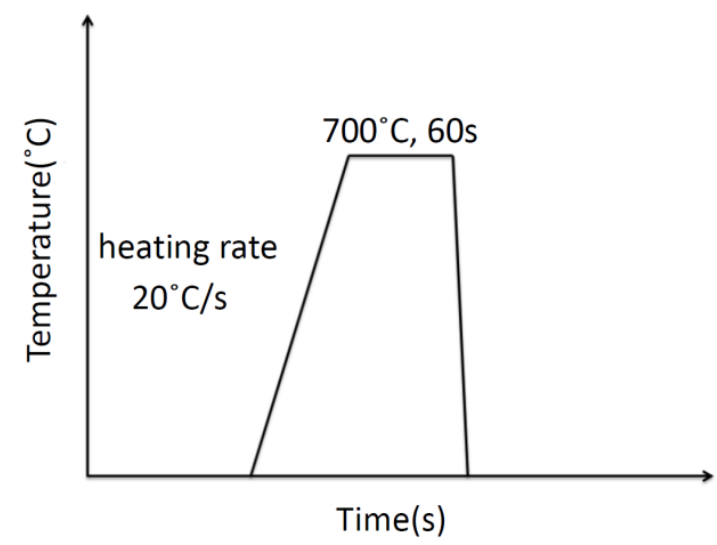

Figure 3. Schemetic of simulated post age hardening heat treatment.

Optical metallography was carried out on a LEICA DMR optical microscope. The samples were hot mounted on a Struers CitoPress-20 mounting machine, then grinded and polished to a $1 \mu \mathrm{m}$ finish using a Struers grinding and polishing machine and etched in $2 \%$ Nital.

Vickers hardness and micro Vickers hardness tests were performed on an INDENTEC Vickers hardness testing machine with a load of $1 \mathrm{~kg}$ and LECO M-400H1 micro Vickers hardness testing machine with a load of 50g, respectively. The Vickers hardness of the samples or micro Vickers hardness of each microstructure constituent was measured as an average of eight tests.

The dilatation curve shown in Figure 4 was obtained by combining the dilatometer data and the microstructure observations of the steel. Microsoft Excel was used to assist in drawing the dilatation curve.

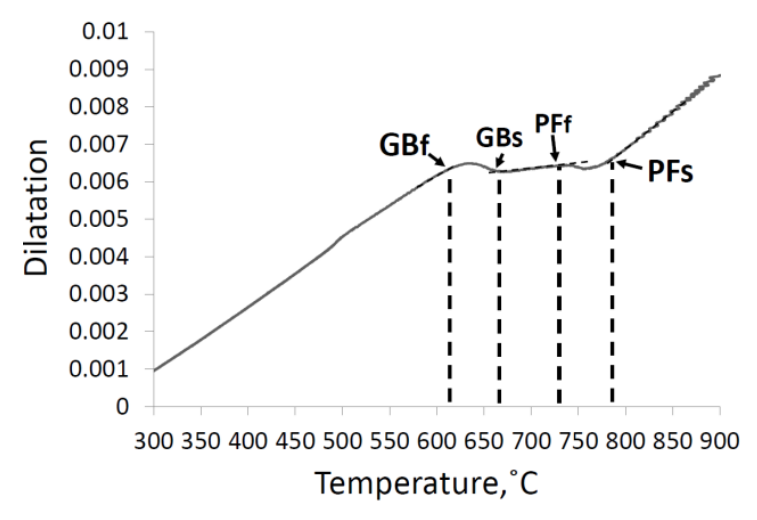

Figure 4. Dilatation cooling curve mapped with the start and stop temperatures for polygonal ferrite (PF) and bainite (GB).

Due to the difficulty in revealing the prior austenite grain boundaries of low carbon UCS steel by using picric acid, the austenite grain boundaries were delineated using ferrite, as shown in Figure 5. The austenite grain size was then measured using the linear intercept method.

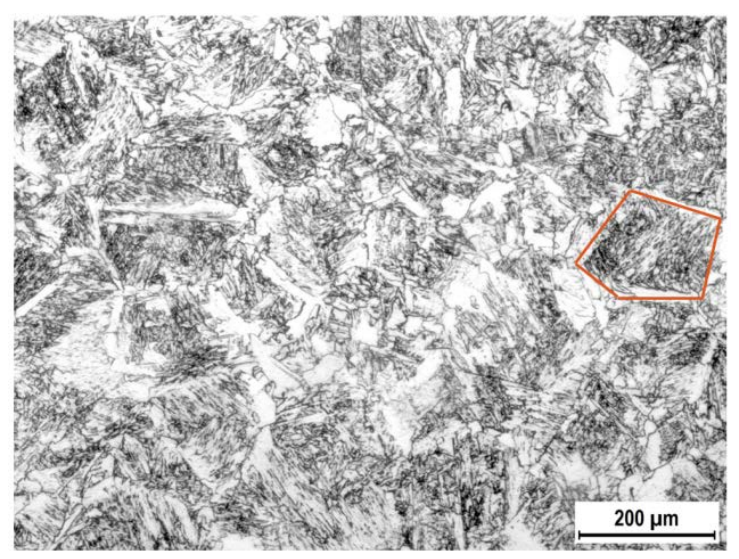

Figure 5. Austenite grain is outlined by grain boundary ferrite.

The volume fraction of each constituent of the samples was estimated by using the imaging analysis software Axiovision and Microsoft Excel. There are a number of nomenclature systems for describing the range of 'lower transformation ferritic products' that form in steel [8-12]. In this paper, the ISIJ transformation products nomenclature [8] was adopted because it is well suited for low carbon steels $[4,8]$. The typical order of ferritic transformation products are: Polygonal Ferrite (PF), Quasi-Polygonal Ferrite (QPF), Widmanstätten Ferrite (aw), Granular Bainite (GB), Bainitic Ferrite (BF) and Martensite.

\section{Results}

\subsection{Microstructure}

The prior austenite grain size was $179 \mu \mathrm{m}$, which is relatively coarse compared with the fine austenite grain size produced during conventional hot rolled strip rolling, and was similar to the austenite grain size produced by 
Table 2: Microstructure summary of the samples cooled at the cooling rates of 1,5 and $40^{\circ} \mathrm{C} / \mathrm{s}$ from $900^{\circ} \mathrm{C}$ to the coiling temperatures of 500 and $675^{\circ} \mathrm{C}$.(PF: polygonal ferrite; P: pearlite; GB: granular bainite and BF: bainitic ferrite)

\begin{tabular}{|c|c|c|c|c|c|c|}
\hline Coiling $\mathrm{T}\left({ }^{\circ} \mathrm{C}\right)$ & \multicolumn{2}{|c|}{500} & \multicolumn{3}{c|}{675} \\
\hline Cooling rate $\left({ }^{\circ} \mathrm{C} / \mathrm{s}\right)$ & 1 & 5 & 40 & 1 & 5 & 40 \\
\hline Microstructure & $\mathrm{PF}+5 \% \mathrm{P}$ & $\mathrm{PF}+29 \% \mathrm{~GB}$ & $\mathrm{~GB}+39 \% \mathrm{BF}$ & $\mathrm{PF}+2 \% \mathrm{P}$ & $\mathrm{PF}+5 \%(\mathrm{~GB}+\mathrm{P})$ & $\mathrm{GB}+45 \% \mathrm{BF}$ \\
\hline
\end{tabular}
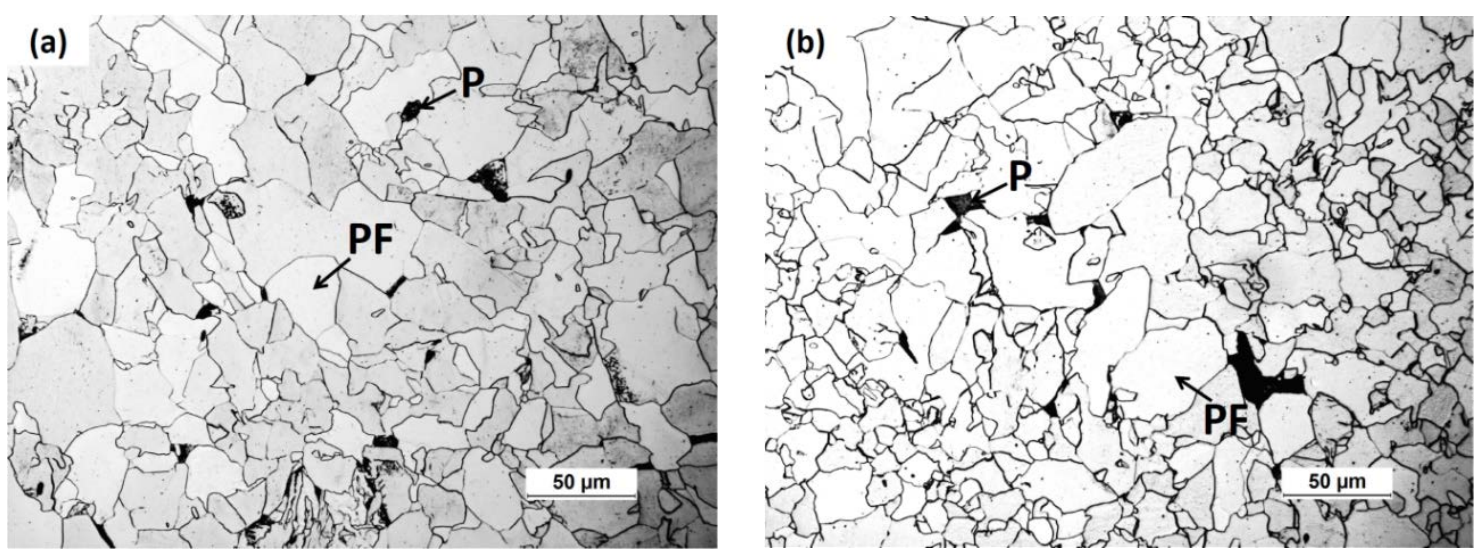

Figure 6. Optical microstructures of the samples cooled at the cooling rate of $1^{\circ} \mathrm{C} / \mathrm{s}$ with the coiling temperatures of (a) $675^{\circ} \mathrm{C}$ (b) $500^{\circ} \mathrm{C}$. (PF: polygonal ferrite; P: pearlite)
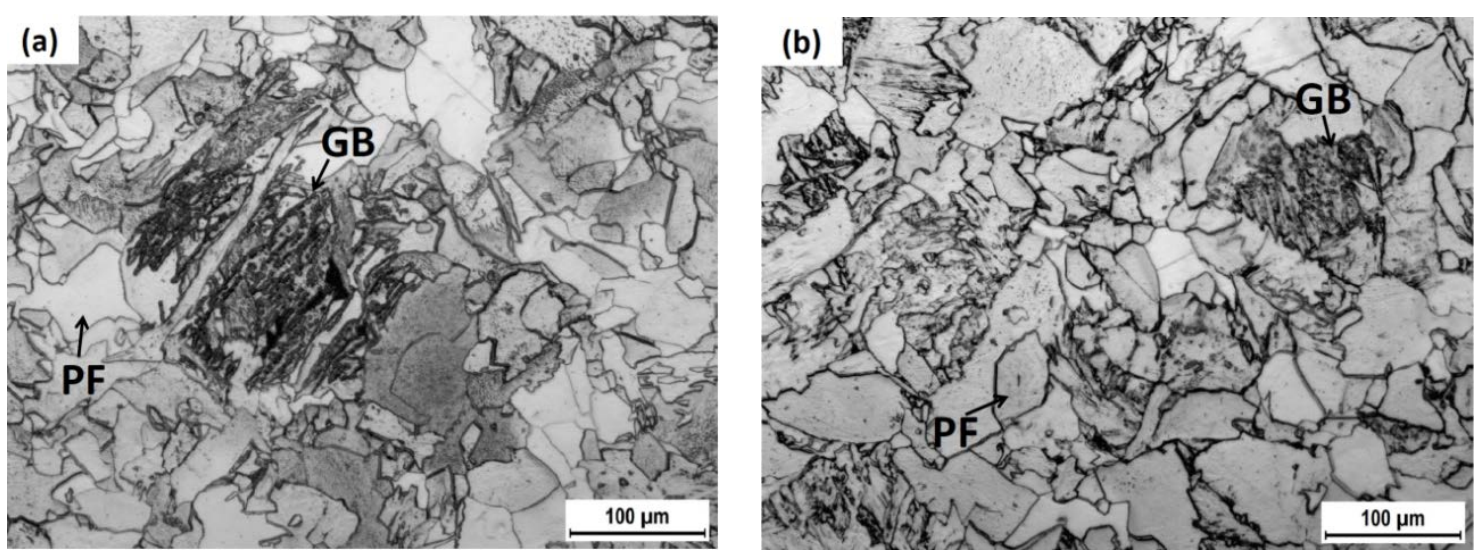

Figure 7. Optical microstructures of the samples cooled at the cooling rate of $5^{\circ} \mathrm{C} / \mathrm{s}$ with the coiling temperatures of (a) $675^{\circ} \mathrm{C}$ (b) $500^{\circ} \mathrm{C}$.( GB: granular bainite; PF: polygonal ferrite)

strip casting by the CASTRIP process of about $180 \mu \mathrm{m}$ [4]. The coarse austenite grain size will retard the austenite transformation process compared with conventional fine grained hot rolled strip steels.

The samples cooled at $1^{\circ} \mathrm{C} / \mathrm{s}$, regardless of the coiling temperature, had a similar microstructure, both consisting of polygonal ferrite and a small amount of pearlite, see Figure 6 . The volume fractions of the polygonal ferrite were $95 \%$ and $98 \%$ for the coiling temperatures of 500 and $675^{\circ} \mathrm{C}$, respectively, as shown in Table 2 .

The microstructure of the samples cooled at $5^{\circ} \mathrm{C} / \mathrm{s}$ varied with the coiling temperature, as shown in Figure 7. At the coiling temperature of $675^{\circ} \mathrm{C}$, the microstructure consisted of about $95 \%$ polygonal ferrite and $5 \%$ pearlite/granular bainite, which is similar to the microstructure of the samples cooled at $1{ }^{\circ} \mathrm{C} / \mathrm{s}$. At the coiling temperature of $500^{\circ} \mathrm{C}$, the microstructure consisted of $71 \%$ polygonal ferrite and $29 \%$ granular bainite.

Figure 8 shows the microstructures of the samples cooled at $40^{\circ} \mathrm{C} / \mathrm{s}$, where both consisted of considerable amounts of granular bainite and bainitic ferrite. For the coiling temperature of $500^{\circ} \mathrm{C}$, the sample consisted of $61 \%$ granular bainite and $31 \%$ bainitic ferrite and for the coiling temperature of $675^{\circ} \mathrm{C}$ the sample consists of $55 \%$ granular bainite and $45 \%$ of bainitic ferrite. The bainitic ferrite is the plate-like ferrite formed first at the austenite grain boundaries and the granular bainite formed in the remainder of the matrix. The size of the bainitic ferrite is much smaller than that of the polygonal ferrite produced in the sample cooled at $5^{\circ} \mathrm{C} / \mathrm{s}$.

\subsection{Dilatation curves}

Figure 9 displays the dilatation curves obtained from the samples in the various cooling conditions, in which 

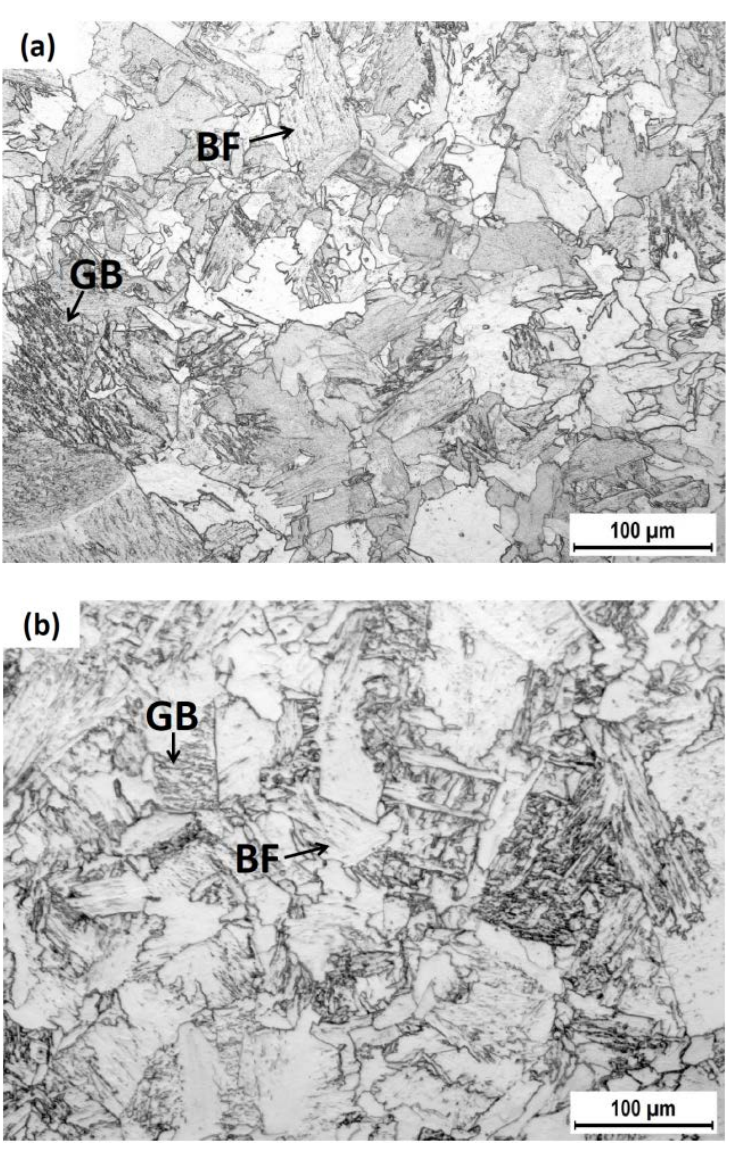

Figure 8. Optical microstructures of the samples cooled at the cooling rate of $40^{\circ} \mathrm{C} / \mathrm{s}$ with the coiling temperatures of (a) $675^{\circ} \mathrm{C}$ (b) $500^{\circ} \mathrm{C}$ (BF: Bainitic ferrite).

the coiling temperatures of 500 and $675^{\circ} \mathrm{C}$ are marked with dotted lines. The $\gamma-\alpha$ phase transformation starting and finishing temperatures are marked with dashed lines. The transformations were mainly produced in the peak and trough of the dilatation curve, which were marked with solid lines. As the entire transformation period was affect by a change in cooling rate, the portion of the transformation between the two points of inflection was also measured, which was termed, 'major' transformation, as it accounts for the majority of the transformation. It is clear that $675^{\circ} \mathrm{C}$ is within the $\gamma-\alpha$ phase transformation temperature range but $500^{\circ} \mathrm{C}$ is outside of the range for all the samples. At the cooling rate of $1^{\circ} \mathrm{C} / \mathrm{s}$, almost all the austenite transformed into polygonal ferrite at the temperature above $675^{\circ} \mathrm{C}$, as shown in Figures 9a and b. This was consistent with the microstructural observations, where the volume fractions of the polygonal ferrite were $98 \%$ and $95 \%$ for the coiling temperatures of $675^{\circ} \mathrm{C}$ and $500^{\circ} \mathrm{C}$ respectively.

In comparison the cooling rate of $40^{\circ} \mathrm{C} / \mathrm{s}$ is too fast for the $\gamma-\alpha$ phase transformation to complete above $675^{\circ} \mathrm{C}$, so only a small amount bainitic ferrite was produced above $675^{\circ} \mathrm{C}$ and a large volume fraction of the austenite transformed into the granular bainite below $675^{\circ} \mathrm{C}$ due to the slow cooling rate of $0.17^{\circ} \mathrm{C} / \mathrm{s}$, as shown in Figure 9e and 9f. Polygonal ferrite did not form during the simulated coil cooling stage, perhaps due to carbon segregation into the remaining austenite, which increased the hardenability, so bainitic ferrite formed. A marked difference between the sample cooled at $1^{\circ} \mathrm{C} / \mathrm{s}$ and the sample cooled at $5^{\circ} \mathrm{C} / \mathrm{s}$ is that the transformation of the austenite to granular bainte occurred in the sample cooled at $5^{\circ} \mathrm{C} / \mathrm{s}$ (Figures 9c and 9d) but not in the sample cooled at $1^{\circ} \mathrm{C} / \mathrm{s}$ (Figures $9 \mathrm{a}$ and $9 \mathrm{~b}$ ). It should be noted that the inflection points in the cooling curves indicate the start and the finish of the phase transformation from $\gamma$ to $\alpha$ in terms of volume as shown in Fig. 9. At the $675^{\circ} \mathrm{C}$ coiling temperature the $\gamma$ to $\alpha$ transformation mainly occurred in the temperature ranges of $789-714^{\circ} \mathrm{C}, 757-668^{\circ} \mathrm{C}$ and $681-657^{\circ} \mathrm{C}$ for the cooling rates 1,5 and $40^{\circ} \mathrm{C} / \mathrm{s}$, respectively. At the $500^{\circ} \mathrm{C}$ coiling temperature, the $\gamma$ to $\alpha$ transformation mainly occurred in the temperature ranges of $799-724^{\circ} \mathrm{C}, 754-638^{\circ} \mathrm{C}$ and $662-577^{\circ} \mathrm{C}$ for the cooling rates 1,5 and $40^{\circ} \mathrm{C} / \mathrm{s}$, respectively. The main $\gamma$ to $\alpha$ transformation range occurred between peak and trough were labelled as shown in Figure 9.

\subsection{Age hardening response}

Table 3 tabulates the Vickers hardness and estimated yield strength of the samples for each of the various cooling conditions, before and after the age hardening heat treatment. The yield strength was converted from the Vickers hardness by conversion equation [13]. The results showed that a hardness increase from the age hardening heat treatments was recorded for all cooling conditions. For the $500^{\circ} \mathrm{C}$ coiling temperature, the age hardening increments were similar for the $1^{\circ} \mathrm{C} / \mathrm{s}$ and $5^{0} \mathrm{C} / \mathrm{s}$ cooling rates, while slightly higher for the highest cooling rate of $40^{\circ} \mathrm{C} / \mathrm{s}$.

The hardness before the age hardening heat treatment was similar for both the coiling temperatures for the cooling rates of 5 and $40^{\circ} \mathrm{C} / \mathrm{s}$, while for the $1^{\circ} \mathrm{C} / \mathrm{s}$ cooling rate, the hardness before age hardening was higher for the $675^{\circ} \mathrm{C}$ coiling temperature, perhaps indicating that some precipitation hardening had occurred.

The micro Vickers hardness and associated estimated yield strength of the various microstructural constitutes are shown in Table 4 . The micro hardness results showed similar hardness increments from the age hardening heat treatment to that recorded from the macro Vickers hardness tests. Moreover, the micro Vickers hardness values for the polygonal ferrite phase were similar to the macro Vickers hardness before the age hardening for the $1^{\circ} \mathrm{C} / \mathrm{s}$ cooling rates for the both coiling temperatures. However, for the other conditions, the micro hardness results were higher than the macro Vickers hardness results, particularly for the samples cooled at $40^{\circ} \mathrm{C} / \mathrm{s}$.

This was most likely due to the micro hardness tests sampling a higher percentage of harder phases, which would be more pronounced for granular bainite, due to the laminar like structure. 



Figure 9. Dilatation curves obtained at the various combinations of cooling rates and coiling temperatures: (a) $1{ }^{\circ} \mathrm{C} / \mathrm{s}, 500^{\circ} \mathrm{C}$ (b) $1^{\circ} \mathrm{C} / \mathrm{s}, 675^{\circ} \mathrm{C}$ (c) $5^{\circ} \mathrm{C} / \mathrm{s}, 500^{\circ} \mathrm{C}(\mathrm{d}) 5^{\circ} \mathrm{C} / \mathrm{s}, 675^{\circ} \mathrm{C}$ (e) $40^{\circ} \mathrm{C} / \mathrm{s}, 500^{\circ} \mathrm{C}$ (f) $40^{\circ} \mathrm{C} / \mathrm{s}, 675^{\circ} \mathrm{C}$ (PF: polygonal ferrite; $\mathrm{BF}$ : bainitic ferrite; GB: granular bainite).

Table 3: Vickers hardness (HV1) and yield strength (MPa) of the samples before and after age hardening.

\begin{tabular}{|c|c|c|c|c|c|c|c|}
\hline $\begin{array}{c}\text { Coiling temp } \\
\left({ }^{\circ} \mathrm{C}\right)\end{array}$ & $\begin{array}{c}\text { Cooling rate } \\
\left({ }^{\circ} \mathrm{C} / \mathrm{s}\right)\end{array}$ & \multicolumn{2}{|c|}{ Before age hardening } & \multicolumn{2}{c|}{ After age hardening } & \multicolumn{2}{c|}{ Age hardening } \\
\cline { 3 - 8 } & 1 & HV & YS & HV & YS & $\Delta$ HV & $\Delta$ YS \\
\hline \multirow{3}{*}{500} & 5 & 178 & 421 & 205 & 499 & 27 & 78 \\
\cline { 2 - 8 } & 40 & 201 & 487 & 233 & 579 & 32 & 92 \\
\cline { 2 - 8 } & 1 & 191 & 459 & 206 & 502 & 15 & 43 \\
\hline \multirow{3}{*}{675} & 5 & 201 & 487 & 211 & 516 & 10 & 29 \\
\cline { 2 - 8 } & 40 & 204 & 496 & 212 & 519 & 8 & 23 \\
\hline
\end{tabular}


Table 4: Micro Vickers hardness (HV 0.05) and estimated yield strength (MPa) of the polygonal ferrite and granular bainite before and after age hardening.

\begin{tabular}{|c|c|c|c|c|c|c|c|c|c|c|c|c|c|}
\hline \multirow{3}{*}{$\begin{array}{l}\text { Coiling } \\
\text { temp } \\
\left({ }^{\circ} \mathrm{C}\right) \\
\end{array}$} & \multirow{3}{*}{$\begin{array}{l}\text { Cooling } \\
\text { rate } \\
\left({ }^{\circ} \mathrm{C} / \mathrm{s}\right)\end{array}$} & \multicolumn{4}{|c|}{ Before age hardening } & \multicolumn{4}{|c|}{ After age hardening } & \multicolumn{4}{|c|}{ Age hardening } \\
\hline & & \multicolumn{2}{|c|}{$\mathrm{PF}$} & \multicolumn{2}{|c|}{$\mathrm{GB}$} & \multicolumn{2}{|c|}{$\mathrm{PF}$} & \multicolumn{2}{|c|}{ GB } & \multicolumn{2}{|c|}{$\mathrm{PF}$} & \multicolumn{2}{|c|}{ GB } \\
\hline & & $\mathrm{HV}$ & YS & $\mathrm{HV}$ & YS & $\mathrm{HV}$ & YS & $\mathrm{HV}$ & YS & $\Delta \mathrm{HV}$ & $\Delta \mathrm{YS}$ & $\Delta \mathrm{HV}$ & $\Delta \mathrm{YS}$ \\
\hline \multirow{3}{*}{500} & 1 & 177 & 418 & - & - & 206 & 502 & - & - & 29 & 84 & - & - \\
\hline & 5 & 185 & 441 & 207 & 505 & 216 & 531 & 243 & 608 & 31 & 90 & 36 & 103 \\
\hline & 40 & - & - & 230 & 571 & - & - & 263 & 666 & - & - & 33 & 95 \\
\hline \multirow{3}{*}{675} & 1 & 192 & 461 & - & - & 217 & 533 & - & - & 25 & 72 & - & - \\
\hline & 5 & 203 & 493 & 221 & 545 & 220 & 542 & 238 & 594 & 17 & 49 & 17 & 49 \\
\hline & 40 & - & - & 227 & 562 & - & - & 239 & 597 & - & - & 16 & 35 \\
\hline
\end{tabular}

Table 5: The $\gamma$ - $\alpha$ phase transformation temperature range and dwell time in the $\gamma$ - $\alpha$ phase transformation temperature range of the samples in various cooling conditions.

\begin{tabular}{|c|c|c|c|c|c|}
\hline \multirow{2}{*}{$\begin{array}{c}\text { Coiling Temp. } \\
\left({ }^{\circ} \mathrm{C}\right)\end{array}$} & $\begin{array}{c}\text { Cooling rate } \\
\left({ }^{\circ} \mathrm{C} / \mathrm{s}\right)\end{array}$ & \multicolumn{2}{|c|}{$\lambda \rightarrow \alpha$ temperature range $\left({ }^{\circ} \mathrm{C}\right)$} & \multicolumn{2}{|c|}{ Dwell time in $\lambda \rightarrow \alpha$ range $(\mathrm{s})$} \\
\cline { 3 - 6 } & 1 & $810-630$ & $799-724$ & 180 & 75 \\
\cline { 2 - 6 } 500 & 5 & $786-615$ & $754-638$ & 34 & 23 \\
\cline { 2 - 6 } & 40 & $735-540$ & $662-577$ & 5 & 2 \\
\hline \multirow{4}{*}{675} & 1 & $810-667$ & $789-714$ & 182 & 89 \\
\cline { 2 - 6 } & 5 & $786-660$ & $757-668$ & 126 & 106 \\
\cline { 2 - 6 } & 40 & $726-640$ & $681-657$ & 207 & 89 \\
\hline
\end{tabular}

Table 5 summarises the $\gamma$ - $\alpha$ phase transformation temperature ranges and the dwell time in the $\gamma$ - $\alpha$ phase transformation temperature range of the samples in the various cooling conditions. It is clear that for the coiling temperature of $500^{\circ} \mathrm{C}$, the dwell time of the sample at the cooling rate of $40^{\circ} \mathrm{C} / \mathrm{s}$ in the major range is just 2 seconds which is as expected much shorter than that of the samples cooled at 1 and $5^{\circ} \mathrm{C} / \mathrm{s}$. For the coiling temperature of $675^{\circ} \mathrm{C}$ the dwell time of the sample in the major region at $1^{\circ} \mathrm{C} / \mathrm{s}$ is 75 seconds which is a little shorter than 89 seconds for the sample cooled at $5^{\circ} \mathrm{C} / \mathrm{s}$ but shorter than 106 seconds for the sample cooled at $40^{\circ} \mathrm{C} / \mathrm{s}$ as shown in Table 5 .

\section{Discussions}

\subsection{Effect of cooling rate and coiling temperature on transformation products}

As the cooling rate increased, the change in ferritic transformation products followed the typical sequence as outlined by ISIJ Bainitic committee [8]. That is, with increasing cooling rate; Polygonal ferrite becomes more irregular in shape, i.e. Quasi-Polygonal ferrite, then bainitic transformations take place, Granular Bainite (G.B.) followed by Bainitic Ferrite (B.F.). Normally, GB forms before $\mathrm{BF}$ [8], but this was not the case for the samples cooled at $40^{\circ} \mathrm{C} / \mathrm{s}$ (See Fig 8). Once BF had exhausted the preferred nucleation sites of the austenite grain boundaries, the intragranular nucleation of GB became more favourable. Nucleation of intragranular GB was possible in this study, due to the large austenite grain size and continuous cooling conditions. The austenite grain size was large enough to prevent $\mathrm{BF}$ from consuming the entire matrix before the temperature dropped low enough for intragranular nucleation to become favourable [4,9]. Granular Bainite has a lath-less, coarse structure, which does not have the classical needle-like structure that is associated with acicular ferrite. In conventional processing, intragranular nucleation is not observed as the austenite grain size is quite small prior to transformation.

\subsection{The effect of the coiling temperature on the $\mathrm{Nb}$ retention in the UCS steel}

Before age hardening, the greatest difference in hardness between the $675^{\circ} \mathrm{C}$ and $500^{\circ} \mathrm{C}$ coiling temperature results was at $1^{\circ} \mathrm{C} / \mathrm{s}$, where the hardness of the sample at $675^{\circ} \mathrm{C}$ was $191 \mathrm{Hv}$, while at $500^{\circ} \mathrm{C}$ is was $178 \mathrm{Hv}$, as shown in Table 3. For the cooling rates of 5 or $40^{\circ} \mathrm{C} / \mathrm{s}$, the hardness of the samples was slightly higher at the coiling temperature $675^{\circ} \mathrm{C}$. However, according to the microstructural analysis (Table 2), more granular bainite was produced at the cooling rate of $5^{\circ} \mathrm{C} / \mathrm{s}$ for the lower coiling temperature. Based on this, the hardness of the sample at $500^{\circ} \mathrm{C}$ should be higher than that of the sample at $675^{\circ} \mathrm{C}$, which is obviously contradictory to the results. The reason for the contradiction is that the strength of the steel is not only determined by grain refinement, but also determined by other strengthening mechanisms, as shown in equation 1 [14].

$$
\sigma_{y}=\sigma_{0}+\sigma_{s}+\sigma_{g}+\sigma_{p}+\sigma_{d}
$$

where $\sigma_{\mathrm{y}}$ is the yield strength, $\sigma_{0}$ is the ferrite lattice strength, $\sigma_{\mathrm{s}}, \sigma_{\mathrm{g}}, \sigma_{\mathrm{p}}$ and $\sigma_{\mathrm{d}}$ are the strengthening contributions caused by solid solution, grain refinement, precipitation hardening and dislocation hardening respectively. Of the above mechanisms, grain refinement hardening and precipitation hardening are the two most 
likely candidates to cause an increase in hardness for the samples in the present study.

From Table 3, at the same cooling rate, the age hardening increment with the low coiling temperature of $500^{\circ} \mathrm{C}$ is much higher than that with $675^{\circ} \mathrm{C}$, which means more $\mathrm{Nb}$ atoms were retained in the solid solution before the age hardening heat treatment during the simulated strip cooling process. Previous studies have shown that microalloy carbides are mainly produced during $\gamma-\alpha$ phase transformation in cooling because there is a large solubility difference of alloy carbides between the austenite and ferrite $[5,15]$. The solubility of $\mathrm{Nb}$ carbides in austenite is much higher than that in ferrite and thus the $\mathrm{Nb}$ carbides will typically precipitate out during $\gamma-\alpha$ phase transformation in a cooling process [16-21]. As can be seen from Figure 9, that $500^{\circ} \mathrm{C}$ is outside of the $\gamma-\alpha$ phase transformation temperature range but $675^{\circ} \mathrm{C}$ is within the range in all the dilatation curves. The cooling rate was just $0.17^{\circ} \mathrm{C} / \mathrm{s}$ below the coiling temperature, so there was sufficient time for the sample with a $675^{\circ} \mathrm{C}$ coiling temperature to dwell in the $\gamma$ - $\alpha$ phase transformation temperature range. This was not the case when coiled at $500^{\circ} \mathrm{C}$, so the time spent during the $\gamma-\alpha$ phase transformation was much shorter Therefore, at the same cooling rate, fewer precipitates, if any, would be expected to be produced in the sample at the lower coiling temperature of $500^{\circ} \mathrm{C}$ compared to the sample at $675^{\circ} \mathrm{C}$. Furthermore, the drive for $\mathrm{Nb}$ precipitation at $500^{\circ} \mathrm{C}$ is very low, so even with the slow coil cooling, $\mathrm{Nb}$ would remain in solid solution.

Consequently, for samples coiled at $500^{\circ} \mathrm{C}$, only microstructural hardening and solid solution hardening occurred, but for samples coiled at $675^{\circ} \mathrm{C}$, precipitation hardening also occurred. Therefore, the pre-aged hardness was higher for samples coiled at $675^{\circ} \mathrm{C}$ for all cooling rates, especially at $1^{\circ} \mathrm{C} / \mathrm{s}$, where both microstructures were polygonal ferrite. The diminished age hardening response for the $675^{\circ} \mathrm{C}$ samples for all cooling rates agrees that a significant amount of $\mathrm{Nb}$ was lost during the cooling process.

\subsection{The effect of cooling rate on the $\mathrm{Nb}$ retention in the UCS steel}

The coiling temperature of $500^{\circ} \mathrm{C}$ is outside of the $\gamma-\alpha$ phase transformation temperature range in all the samples, so the dwell time of the samples in the phase transformation range depends on the cooling rate. The higher the cooling rate the shorter the dwelling time, thus $\mathrm{NbC}$ precipitation is less likely. It is expected that more $\mathrm{Nb}$ will be retained in the samples cooled at the high cooling rate of $40^{\circ} \mathrm{C} / \mathrm{s}$ than the samples cooled at the lower cooling rates of 1 and $5^{\circ} \mathrm{C} / \mathrm{s}$.

As expected for the same coiling temperature of $500^{\circ} \mathrm{C}$, the age hardening of the samples cooled at $40^{\circ} \mathrm{C} / \mathrm{s}$ is the highest at $32 \mathrm{Hv}$, as shown in Table 3 . At the cooling rate of $40^{\circ} \mathrm{C} / \mathrm{s}$, it is clear from Table 5 that the dwelling time of the samples in the major $\gamma-\alpha$ phase transformation temperature range is the shortest, giving the least time for NbC to precipitate.

The $675^{\circ} \mathrm{C}$ coiling temperature is within the $\gamma$ - $\alpha$ phase transformation temperature range, which renders the interpretation of the age hardening results more complex.
For example, the age hardening increment was higher at the lower cooling rate compared with the faster cooling rates, indicating that more $\mathrm{Nb}$ was retained in solution at the slower cooling rate through the transformation, rather than at the higher cooling rates, which was not expected.

At the cooling rate of $1^{\circ} \mathrm{C} / \mathrm{s}$, most of the austenite had transformed into polygonal ferrite above the coiling temperature of $675^{\circ} \mathrm{C}$, as shown in Figure 9a. While the very slow cooling below the coiling temperature of $675^{\circ} \mathrm{C}$ would add to the transformation time, there was very little phase transformation left to occur. Therefore, the $\gamma-\alpha$ phase transformation and NbC precipitation mainly occurred above the coiling temperature of $675^{\circ} \mathrm{C}$ for the sample cooled at $1^{\circ} \mathrm{C} / \mathrm{s}$. In contrast, the samples cooled at the higher cooling rate, such as $40^{\circ} \mathrm{C} / \mathrm{s}$, only some of the austenite had transformed into bainitic ferrite above the coiling temperature of $675^{\circ} \mathrm{C}$ (Figure 9e). A larger volume fraction of the austenite transformed into the granular bainite at the temperature range below $675^{\circ} \mathrm{C}$ at the cooling rate of only $0.17^{\circ} \mathrm{C} / \mathrm{s}$. Such a slow cooling rate will enable more $\mathrm{Nb}$ to precipitate out as $\mathrm{NbC}$ and less $\mathrm{Nb}$ was retained in solid solution for the age hardening. As can be seen from Table 5, the dwell time of the sample in the major $\gamma$ - $\alpha$ phase transformation range at $40^{\circ} \mathrm{C} / \mathrm{s}$ is much longer than that of the sample at $1^{\circ} \mathrm{C} / \mathrm{s}$. The nucleation sites for the $\mathrm{NbC}$ precipitate during the $\gamma$ $\alpha$ phase transformations for the samples at $40^{\circ} \mathrm{C} / \mathrm{s}$ are mainly the interfaces between the $\gamma$ and $\alpha$. The number of the nucleation sites is related to the volume transformation of the $\gamma \rightarrow \alpha$ and therefore it is likely that more $\mathrm{NbC}$ precipitated in the sample cooled at $40^{\circ} \mathrm{C} / \mathrm{s}$ than in the sample cooled at $1^{\circ} \mathrm{C} / \mathrm{s}$ to the coiling temperature of $675^{\circ} \mathrm{C}$ before the aging hardening treatment. As for the sample cooled at the cooling rate of $5^{\circ} \mathrm{C} / \mathrm{s}$, the dwell time of the sample in the major $\gamma-\alpha$ phase transformation was also longer than that of the sample at $1^{\circ} \mathrm{C} / \mathrm{s}$, as shown in Table 5 . This implies that less $\mathrm{Nb}$ was retained in the solid solution of the sample cooled at $5^{\circ} \mathrm{C} / \mathrm{s}$ than the sample cooled at $1^{\circ} \mathrm{C} / \mathrm{s}$. This is consistent with the results that larger age hardening was obtained in the sample cooled at $1^{\circ} \mathrm{C} / \mathrm{s}$ than the sample cooled at $5^{\circ} \mathrm{C} / \mathrm{s}$ as shown in Table 3 .

\section{Conclusions}

1. The hardness of the UCS steel is not only determined by the microstructures, but also determined by precipitates produced during CASTRIP process. The findings suggest that even if more granular bainite were produced in the sample with the lower coiling temperature of $500^{\circ} \mathrm{C}$, the hardness of the samples cooled to $675^{\circ} \mathrm{C}$ was higher due to precipitation hardening

2. The cooling rate effect on the $\mathrm{Nb}$ retention was very clear for the samples which have the coiling temperature of $500^{\circ} \mathrm{C}$. The faster cooling rates results in lower $\gamma-\alpha$ transformation temperatures and the specimens spent less time in the $\gamma$ - $\alpha$ transformation temperature range, so more $\mathrm{Nb}$ was retained in solid solution and a large age hardening increment was produced.

3. The cooling rate effect on the $\mathrm{Nb}$ retention was complicated for samples coiled at $675^{\circ} \mathrm{C}$, because the coiling temperature was within the $\gamma$ - $\alpha$ transformation range. Due to the simulated slow coil cooling, there was 
ample time for $\mathrm{Nb}$ to precipitate, thus diminishing the age hardening response for all cooling rates.

4. High coiling temperatures should be avoided for the CASTRIP Process for Nb-bearing steels to prevent unwanted $\mathrm{Nb}$ precipitation during coiling and therefore, diminishing the age hardening response of the product.

\section{Acknowledgements}

The authors would like to thank BlueScope for supplying the samples and Dr Liang Chen for help with the dilatometer experiments.

\section{References}

[1] P. Campbell, W. Blejde, R. Mahapatra, R. Wechsler, G Gillen, The Castrip Process - Direct Casting of Steel Sheet at Nucor Crawfordsville, Iron and Steel Technology, (2005) 56.

[2] Sachin L. Shrestha, Kelvin Y. Xie, Chen Zhu, Simon P. Ringer, Chris Killmore, Kristin R. Carpenter, Harold Kaul, James G. Williams, Julie M. Cairney, Cluster strengthening of Nb-microalloyed ultra-thin cast strip steels produced by the CASTRIP ${ }^{\circledR}$ process, Materials Science \& Engineering A, 568 (2013) 88-95

[3] C. Killmore, K. Carpenter, H. Kaul, J. Williams, D. Edelman, P. Campbell and W. Blejde, Development of a Family of High Strength Low Carbon Microalloyed Ultra-Thin Cast Strip Products Produced by the CASTRIP ${ }^{\circledR}$ Process, Proceedings MS\&T Conference, Oct 17-21, Texas, (2010) 1711- 1726

[4] Carpenter, K.R., Killmore, C.R., The effect of Nb on the continuous cooling transformation curves of ultra-thin strip CASTRIP $@$ steels, Metals, 5 (4), (2015) 1857-1877.

[5] Shrestha, S.L., Zhu, C., Proust, G., Barbaro, F., Killmore, C., Carpenter, K., Kaul, H., Xie, K.Y., Ringer, S.P., Cairney, J.M., An overview of the effect of $\mathrm{Nb}$ in strengthening Castrip ${ }^{\circledR}$ steel, Materials Science Forum, 753, (2013) 559-562.

[6] Chen, C. Y., et al., Microstructural characterization and strengthening behavior of nanometer sized carbides in Ti-Mo microalloyed steels during continuous cooling process, Materials Characterization, 114 (2016) 18-29.

[7] Simoneau, R., et al., Progress of nbcn precipitation in hsla steels as determined by electrical resistivity measurements, Met Sci, 12(8) (1978) 381-386.

[8] Araki, T.; Kozasu, I.; Takechi, H.; Shibata, K.; Enomoto, M.; Tamehiro, H.; Yamamoto, S.; Katumata, M.; Okaguchi, H.; Amao, K.; et. al, Atlas For Bainitic Microstructures, Iron Steel Inst. Jpn., 1 (1992) 1-20.
[9] Dunne D.P., Ferrite Morphology and residual phases in continuously cooled low carbon steels, Materials Forum, Vol. 23 (1999) 63-76.

[10] Bramfitt B.L. and Speer J.G. (1990), A perspective on the morphology of Bainite, Met. Trans A, 21A, 4 (1999) 817-829.

[11] Ohtani H.; Okaguchi S.; Fujihiro Y.; and Ohmori Y. Morphology and properties of low-carbon bainite, Met. Trans, A, 21A, 3 (1990) 877-887

[12] Zajac S.; Schwinn V. and Tacke K.H.; Characterisation and Quantification of Complex Bainitic Microstructures in High and Ultra-High Strength Linepipe Steels, in Int. Symposium on Microalloying for New steel processes and applications, Sept. 7-9, 2005, San Sebastian, Spain, Mater. Sci. Forum, 500-501, 387394.

[13] Pavlina, E. J. and C. J. Van Tyne, Correlation of Yield Strength and Tensile Strength with Hardness for Steels, Journal of Materials Engineering and Performance , 17(6) (2008) 888-893.

[14] S.K. Ghosh, P.S. Bandyopadhyay, S. Kundu, S. Chatterjee, Copper bearing microalloyed ultrahigh strength steel on a pilot scale: Microstructure and properties, Mat. Sci. Eng. A, 528 (2011) 7887-7894.

[15] Proceedings of Microalloying 75 Conference, Washington DC, USA, (1975) 85-87.

[16] H. Beladi and P. D. Hodgson, Effect of carbon content on the recrystallization kinetics of Nb-steels, Scripta Materialia, 56 (2007) 1059.

[17] S. Akamatsu, M. Hasebe, T. Senuma, Y. Matsumura and O. Akisue, Thermodynamic calculation of solute carbon and nitrogen in $\mathrm{Nb}$ and Ti added extra-low carbon steels, ISIJ Int, 34 (1994) 9.

[18] K. J. Irvine, F. B. Pickering and T. Gladman, Grain Refined C-Mn Steels, J. Iron Steel Inst, 205 (1967) 161.

[19] P. R. Rios, Expression for solubility product of niobium carbonitride in austenite, Mater. Sci. Technol, 4 (1988) 324

[20] H. Sawamura and T. Mori, Thermodynamic investigation of non-metallic inclusions in steel (ii), J. Iron Steel Inst, 43 (1957) 31.

[21] R. W. Fountain and J. Chipman, Solubility and precipitation of boron nitride in iron-boron alloys, Trans. AIME, 224 (1962) 599. 